\title{
Evaluation Strategies and Tactics of immigration Issues in Social Media Discourse
}

\author{
Nazira S. Iskakova ${ }^{1}$, Aibarsha Islam ${ }^{1}$ \\ ${ }^{1}$ Kazakh Ablai khan University of Foreign Relations and World Languages, Almaty, \\ Muratbayev Str., 200, 050022, Kazakhstan.
}

\begin{abstract}
The article is aimed at studying the main evaluation strategies and tactics through contextual analysis of immigration problems in the British social media discourse. The article considers evaluation as a cognitivepragmatic phenomenon and identifies it as a powerful means of persuasion for manipulating public opinion. The commutative strategies and tactics are defined as the main tools to achieve the author's pragmatic intention and the goal. Thus, it has become relevant to identify what evaluation strategies and tactics the author uses to highlight immigration issues in British society. As a result, the diversity of examples allows us to conclude that a key evaluation strategy of British media discourse that presents the immigration issues is a strategy of disapproval, expressed through the tactics of a recognition of the existence of the problem, accusation, reproach, discredit, misunderstanding, doubt, indication of the future, disagreement and distancing that imply negative evaluation.
\end{abstract}

Key words: Evaluation, Evaluation strategy, Evaluation tactics, Manipulation, Media discourse.

\section{Introduction}

In cognition of the surrounding world, a person inevitably evaluates the phenomena, and facts of reality, expressing his subjective attitude to them, which can be reflected through the language. Being one of the tools of persuasion evaluation is identified as a powerful cognitive mean of influence on human consciousness, its picture of the value, as well as a mean of public manipulation. This way, the intensity of evaluation in persuasion may be different as far as evaluation as a universal phenomenon permeates all the activities of human consciousness and existence. Therefore, evaluative action is not only cognitive, but also pragmatic in nature. Thus, evaluation as a cognitivepragmatic phenomenon is characterized as a special linguistic phenomenon that expresses an emotional attitude in speech caused by the existing opinion about the subject of the statement, and is associated not only with mental activity, but also with the communicative activity of a person.

According to recent studies, evaluation has been identified as "the broad cover term for the expression of the speaker or writer's attitude or stance towards, viewpoint on, feelings about the entities or propositions that he or she is talking about" (Hunston \& Thompson, 2000, p. 5). It thus means that through evaluation, the speaker or writer convinces the addressee of his ideas as well as forms the other person's attitude towards different processes.

As a tool for the analysis of the evaluation, we also refer to the appraisal theory by J. Martin \& P. White (2005), developed within the framework of the systemic-functional linguistics of $\mathrm{M}$. Halliday (2004). "The Appraisal framework is an approach to evaluative language in line with

(C) AesthetixMS 2020. This Open Access article is published under a Creative Commons Attribution Non-Commercial 4.0 International License (http://creativecommons.org/licenses/by-nc/4.o/), which permits non-commercial re-use, distribution, and reproduction in any medium, provided the original work is properly cited. For citation use the DOI. For commercial re-use, please contact editor@rupkatha.com. 
systemic-functional linguistics, in the sense that meaning-making is conceived as a choice among different terms in a system" (Martin, 2000, p. 145). In this view, appraisal is a system that is arranged at the level of text semantics (discourse semantics) and is implemented by a wide range of lexical and grammatical means in three interacting subsystems: attitude, graduation and engagement. All these subsystems are related to each other and closely connected to people's feelings, behavior, emotions, judgements, evaluation and attitude (Martin \& White, 2005).

With regard to the main evaluation functions, Thompson and Hunston (200o) identify three important evaluation functions "expressing speaker/writer opinions that reflect their value systems and those of their community, constructing relationships between speakers and readers, and organizing text" (Hunston \& Thompson, 2000, p. 6). In this case, the correlation of evaluation with specific communicative speech situation creates a special type of speech that is evaluative and emotional statement, built on value judgments, which is considered as the speaker /writer's evaluation.

After all, there are different ways to use evaluation expressions while characterizing the same object and the choice is never random. This means that the same theme, source, and structure of the event will look different, even in papers with similar views. Moreover, there are many other techniques, not so obvious, but not less significant by the results of persuasion. They affect, first, the value picture of the other person's world, secondly, his behavior, and thirdly, his emotional state. All these features make evaluation a strong manipulative tool. Thus, evaluation is characteristic for both individual language units and the entire text.

Evaluation of the media text can be manifested in different ways and with the help of multilevel units, for instance, the author's selection of text, the choice of an exact vocabulary, stylistic techniques, syntactic constructions, citation manners, etc. All these tools contribute to the overall evaluation, and within the further studies, it will be perspective to identify which tool in the particular text is primary or which tool prevails.

Nowadays the study of anthropocentric categories, which include evaluation, and the possibility of persuasion on the participants of the communicative process is the most effective as a part of pragmatic approach. Overall, this article attempts to identify the main evaluation strategies and tactics of the author, implemented in the social media discourse in terms of modern pragmatics and cognitive linguistics by analyzing the problems of immigration.

In accordance with the analysis of the data in the present article, two questions were addressed:

1) What strategies and tactics did the author use to express a positive or negative evaluation to influence the recipient?

2) What is the key strategy that best covers the social problems of immigration?

\section{Evaluation Strategies and Tactics}

There is no doubt that the communicative strategy of the author's evaluation is always connected with the search for adequate ways and means of its expression. However, they can be different depending on the type of text, message, motivation, focus, etc. As a result, this makes us perceive the text not as the sum of individual units, but as a whole unity. Moreover, evaluation is invariably associated with the persuasion of the text, since evaluation, along with other communication 
strategies, helps the author not only to inform, but also to achieve maximum impact on the reader, to change and accurate his picture of the world.

T. A. van Dijk and W. Kintsch (1988) distinguish propositional strategies, strategies of local coherence (connectivity), production strategies, and macrostrategies. Some other researchers distinguish schematic, scenario strategies, stylistic and conversational strategies (Tannen, 1989; Gumperz, 1982). Mostly, classification of strategies varies due to the diverse communicative goals of the speaker. For example, based on communicative intention of the speaker: 1) discursive strategies aimed at structuring, organizing discourse depending on the situation, context, intentions, and so on. 2) rhetorical strategies that influence the partner using the rhetorical techniques; 3 ) compensatory strategies aimed at correcting communicative errors (Actafurova, 1997, p. 4). Despite this, the question of the classifying of communicative strategies does not yet have a definite answer. Since the typological description of communicative strategies should take into account the pragmatic factors of the speech situation and the communication sphere of participants.

In Russian Linguistics, O. Issers (2008) presents the entire classification of strategies. The scientist identifies general and private strategies. Private strategies are aimed at solving specific, "urgent" issues. General strategies are used to solve problems of social importance. In this view, the important social problems may cover such issues as public health, immigration, unemployment, education, social security of citizens, etc. All these issues based on social communication that has now spread to the media and everyday social discourse, where it appears in news discussions on social issues. This indicates new discursive forms implemented in the media and social discourse, such as the emergence of speaking points of view (expert, citizen), redefinition of the role of the journalist (author) as an intermediary between the subject and the society, the use of specific forms of intertextuality and the interweaving of scientific elements in general social discussions. Thus, the social media discourse is focused on social problems that are the subject of social experience, which directly concern the person as a social being. Like other types of media discourse, the feature of influencing the addressee characterizes social media discourse. In addition to many language tools, communication strategies are also used to create evaluations that are used to implement impact effects. They are a system of certain ways within a determined communication, defining the choice of language tools and modes of expression related to the achievement of the goal. That is, a communication strategy includes a number of tactics and is understood as a productive way of impact on the recipient.

\section{Data and Methodology}

The data of the analysis is based on online news articles taken from the news websites: Guardian.co.uk, the second most popular online newspaper and Independent.co.uk, the British online daily newspaper. In total, more than 50 news articles have been analyzed on topics covering the main problems of social inequality in connection with the increased number of immigrations of the population of Britain and related socio-political consequences faced by modern British society. The material for the analysis were chosen from the online edition selected by the continuous sampling method for the last three years. We have also used method of a contextual analysis and comparative analysis to determine how positive and negative evaluations were expressed through the strategies and tactics used by the author based on the two research questions addressed in the article. 


\section{Results}

It is obvious today that the British current mass media news on immigration are closely connected with the Brexit process, as it is seen as one of the main important issues facing the country. General pragmatic focus of news devoted to Brexit is expressed in the author's intention to form a certain pragmatic meaning of perception in the addressee by creating an exact image, for example, positive or negative consequences of Brexit for social life. Since the immigration has become one of the most important and discussed issues, the opposing parties accused each other of racism, intolerance, fascism, betrayal of the interests of the people, narrow-mindedness, and economic illiteracy and so on.

Firstly, based on the results of the continuous sampling method, all analyzed articles are divided into two groups. The first group includes supporters of leaving the EU, which argued that the collapse of the economy and infrastructure threatens them, because all places are occupied by cheap labor from other countries, and the health and education systems simply cannot cope with such an influx of new citizens. "According to a survey conducted by the Daily Mail in February 2014, $70 \%$ of the country's population is against immigration" (Glushko et al., 2019, p. 112). Thus, we can say, that a fairly high percentage of the population is against immigration. As for the second group, it consists of EU supporters who claim that there will be a complete collapse, because there will simply be no one to work.

Secondly, we attempted to identify the basic evaluation communicative strategies that are used to express both positive and negative evaluation of the addresser in the social media discourse. Since any discourse of mass communication has a pragmatic focus to influence the audience by means of certain strategies and tactics, which in turn reflect the purpose and position of the author. Based on various classifications, we tried to identify the main evaluation strategies that consist of 1 ) the strategy of approval, 2) the strategy of disapproval, 3) the strategy of unambiguity positions and 4) the strategy of conveying plurality of opinions. Among them, a positive evaluation is expressed through the strategy of approval, while a negative evaluation is expressed by means of disapproval strategy. As for the strategy of unambiguity of positions and the strategy of conveying plurality of opinions, they depend entirely on the context whether it is positive or negative.

These strategies are implemented through different opposite tactics. First, let us consider the strategy of disapproval. As we have already mentioned, it is the best illustration of a negative evaluation. It involves various tactics. One of them is a recognition of the existence of the problem. For example,

If our immigration is solely targeted at "the brightest and the best", the inference is that the low-paid roles will be filled by existing UK citizens. Filling the high-skill needs of our economy by immigration might be cheaper and quicker than tackling the root causes of the shortfall, but in the long run failure to address these issues will create more and bigger problems in the future (Wallis, 09.11.2019).

Here, the tactics of a recognition of the existence of the problem and indication of the future are used simultaneously. That is, the main problem mentioned in the context is that the privilege will be given only to high - skilled workers from other countries, which consequently creates another problem for the main residents of Britain. Due to the lack of labor, this may turn into bigger problems for the population in the future.

Let us consider the next example. 
"I think Brexit is madness," she said. "I don't think they needed to come out of the EU. It is very sad that Brexit is destroying the UK. We have been affected by this uncertainty. There is so much uncertainty and we just wanted to go home" (Dragoi, 31.03.2019).

This context illustrates the negative evaluation that is expressed by tactics of accusation and reproach. Many immigrants compare Brexit to uncertainty. Their rights are violated. Many of them have moved to this country in search of stability, a good life, a good income and some other reasons. Thus, they accuse and rebuke Brexit for this uncertainty.

The tactic of doubt is illustrated in the following example:

"Every day I have anxiety in my head. I'm tired. I just want to live and forget about Brexit and start again. " "I don't have any papers to confirm I have settled status. It's all on a system at the Home Office. I am actually scared that my future is in their hands, " he said (Parveen, 03.10.2019).

According to the addresser, he is in doubt about his future because it is not in his hands. We can also note how clearly his speech describes the feelings of anxiety and tiredness as a negative result of this long process.

One more tactic of the disapproval strategy is the disagreement:

....We should have a fair and balanced immigration system, of course we should, but he is imposing a tax on nurses coming from the EU and beyond to come and work here in our NHS, to care for our sick and our elderly, " Ashworth said, adding that this would exacerbate the NHS staffing crisis (Proctor \& Perraudin, 08.12.2019).

In this context, the author does not express his position of disagreement explicitly, but he does it implicitly by using the modal verb "should". He points out that the immigration system should be fair and balanced, however this is not the case. And it is evidenced by the next following sentence which explains why the immigration system is not fair and balanced.

As we have mentioned above the positive evaluation of the author on immigration issues can be seen in the examples that are illustrated through the strategy of approval. For example,

"It is quite clear that the country needs immigration, and contrary to the soundbites and vague statements that provide a poor substitute for government policy, we need immigrants to fulfil a wide range of roles" (Wallis, 09.11.2019).

This passage includes tactic of ways to solve the problem, by listing the existing problems in society, and the solution in this case is to keep immigration. Thus, it is possible to trace a positive evaluation of the author on immigration, despite that the author used negative vocabulary.

The tactic of a gratitude and recognition of merit is used in the next passage, to express the positive evaluation of the addresser.

A government spokesperson said: "EU workers play a vital role across the health and social care system and we continue to encourage those living and working in the UK to apply for status under the EU settlement scheme (Parveen, 03.10.2019).

In the following macro context, the positive evaluation is expressed by the tactic of indication of success. Most of all, this tactic is used by means of different positive parts of speech, such as: adjectives, nouns, verbs and so on.

A Home Office spokesman said the report's estimated costs "are entirely speculative" 
"To attract the talented workers we need we are bringing forward a new skills-based Immigration system, which is designed to drive up wages and productivity across the UK, " he said.

"This will include supporting businesses by stripping out bureaucracy through streamlining and digitising the system and committing to process the vast majority of work visas within three weeks."The scheme to give EU nationals settled status in the UK was "simple and straightforward", he added (Walker, 11.02.2019).

As for the strategies of unambiguity positions and the strategy of conveying plurality of opinions, in many cases they depend on the context situation. They can express both positive and negative evaluations, as evidenced by the analysis of examples. So, let us consider the strategy of unambiguity positions that involves the tactics of confidence, advice and appeal.

In this example, it can be seen that the assertive speech of the author vividly describes his/her confidence about the full control of British immigration system, even after its exit from the EU.

For the first time in a generation, we will have full control of our immigration system. "Immigration Enforcement has well-established procedures to deter and tackle illegal immigration and illegal working, and this will not change after the UK has left the European Union (Kentish, 16.05.2019).

In the following sentence, we can notice the use of two tactics, the tactics of advice and appeal.

A Home Office spokesperson said: "We have done far more [for EU citizens] than any other EU member state has done for British citizens, and it's time they adopted a similarly generous approach..." (Rankin, 15.01.2020).

As it is clearly seen in the above context, the addresser advises and at the same time appeals EU that "it's time to adopt a similarly generous approach".

The next strategy is the strategy of conveying plurality of opinions, which includes the tactics of a comparative analysis and an indication of differences. In the following example, we can also notice that two and more tactics are used simultaneously. For instance,

Like many other Europeans living in Britain, I can only deal with May's comments by refusing to accept that the prime minister was speaking for the country when she used these hurtful words. The British people I know are welcoming, not hostile. They want to help, not reject. They are compassionate, not cruel. They are simply not like her (Gonzalez Duranrez, 26.11.2018).

So, first, the addresser compares and second, indicates the differences of the behaviour of T. May and ordinary people, as well as their attitude to immigrants. Compared to T. May's negative attitude, people express a positive attitude. What was also noticed that analyzing the similar examples, we came to conclusion, that multiplicity opinions is subordinated to the strategy of unambiguity of the position, as it is clearly seen in the beginning of the example, where the author, through his position, expresses the position of many immigrants.

Provided analysis shows the use of evaluation strategies and tactics on specific examples are related to the data. What we can notice in the examples is that in the majority of them the addresser is able to use various strategies and tactics simultaneously to express his position more vividly. Moreover, many authors intentionally use the speech of the immigrants themselves to reinforce the 
negative evaluation value. Thus, creating much negative images of Brexit in the minds of the addressees. Almost all of these examples are associated with a negative evaluation of the whole immigration situation in the country, they convey a distrustful attitude, negative associations and an uncertainty for the future.

Another finding is that according to the results of the analysis, the positive and negative evaluations expressed by author through the strategies listed above generally point to certain qualities of immigrants. For example, from a positive and negative point of view can be expressed personal qualities, empathy, feelings, employment status, reasons for immigration, and others. The following table shows the percentage of these qualities as they are used in the news (Table 1).

Table 1. The percentage of qualities

\begin{tabular}{|c|c|c|c|c|}
\hline & Positive evaluation & $\%$ & Negative evaluation & $\%$ \\
\hline $\begin{array}{l}\text { personal } \\
\text { qualities }\end{array}$ & $\begin{array}{l}\text { courage, interesting, } \\
\text { cheerful, respectful, good; }\end{array}$ & $60 \%$ & $\begin{array}{l}\text { cunning, impudent, bad, } \\
\text { wild, closed, secretive, } \\
\text { dissatisfied, aggressive; }\end{array}$ & $65 \%$ \\
\hline empathy & $\begin{array}{l}\text { help, infringement of rights, } \\
\text { wandering, helpless, poor } \\
\text { man, pity, in need of } \\
\text { protection, condescension, } \\
\text { insecure; }\end{array}$ & $70 \%$ & $\begin{array}{l}\text { escaped, come in large } \\
\text { numbers, uninvited guest, } \\
\text { not a patriot, burden; }\end{array}$ & $45 \%$ \\
\hline feelings & $\begin{array}{l}\text { excitement, interest, } \\
\text { pleasure; }\end{array}$ & $80 \%$ & $\begin{array}{l}\text { homesickness, } \\
\text { anxiety, stress, } \begin{array}{r}\text { desperate, } \\
\text { destration, } \\
\text { confusion, }\end{array} \\
\text { separation, disappointment; }\end{array}$ & $60 \%$ \\
\hline $\begin{array}{l}\text { employment } \\
\text { status }\end{array}$ & $\begin{array}{l}\text { skills-based, talented } \\
\text { workers, the brightest and } \\
\text { the best; }\end{array}$ & $50 \%$ & $\begin{array}{l}\text { unemployed, cheap labor, } \\
\text { janitor, unskilled labor, low- } \\
\text { skilled labor, low-paid work; }\end{array}$ & $70 \%$ \\
\hline $\begin{array}{l}\text { reasons for } \\
\text { immigration, }\end{array}$ & $\begin{array}{l}\text { search for a better life, new } \\
\text { opportunities, adventure, } \\
\text { prospects, desire to change } \\
\text { life, new experiences; }\end{array}$ & $50 \%$ & $\begin{array}{l}\text { political asylum, disaster, } \\
\text { survival, despair, lack of jobs, } \\
\text { job search, forced, victims, } \\
\text { difficult life situation, rescue, } \\
\text { escape, fatigue, unsettled, } \\
\text { instability; }\end{array}$ & $80 \%$ \\
\hline
\end{tabular}




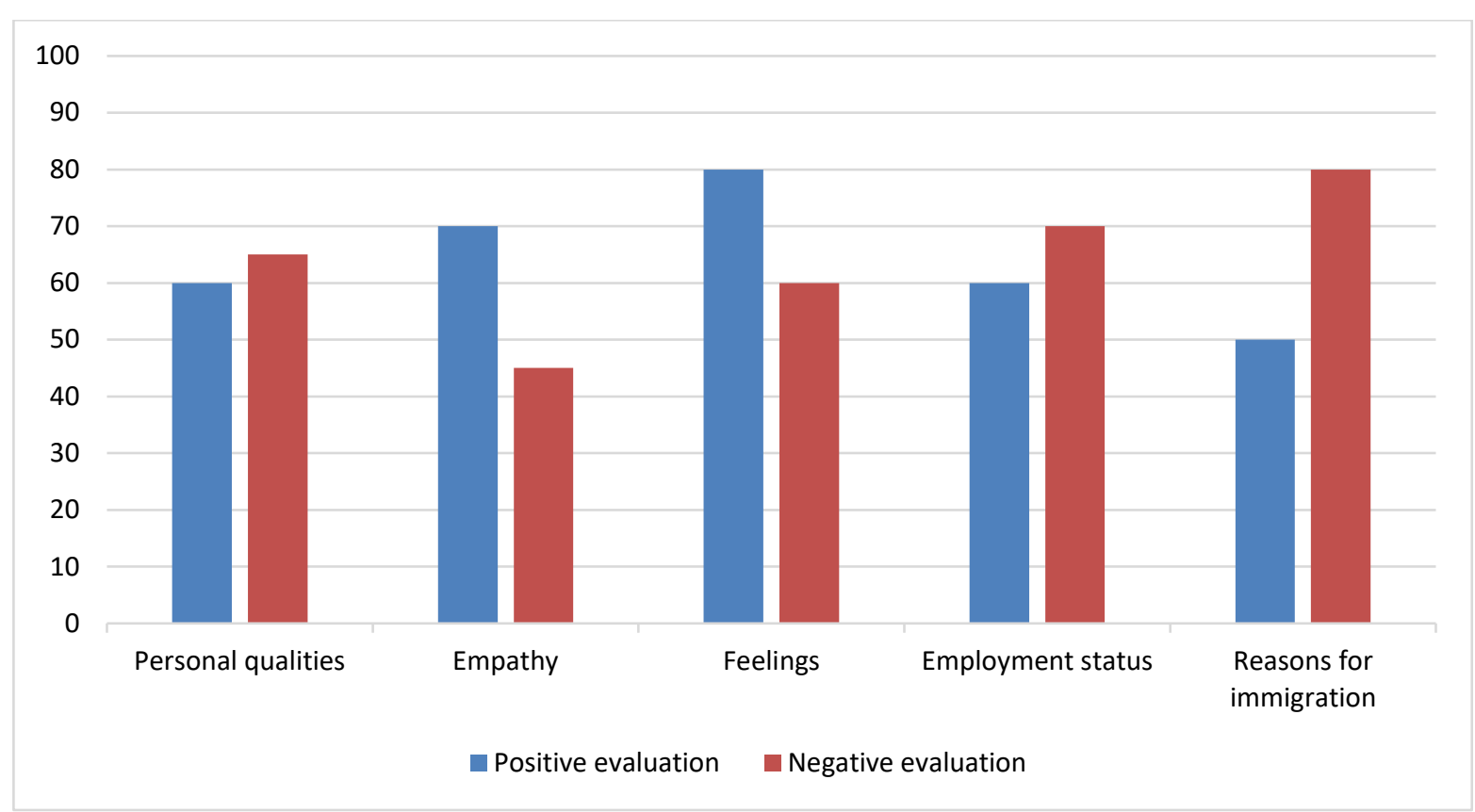

Figure 1. Comparative analysis of positive and negative evaluation qualities

Provided analysis (Figure 1) of evaluation features allow us to conclude that both positive and negative attitudes towards immigrants are recorded in the language consciousness of the British society. A positive attitude can be noticed in their sympathy and experience towards immigrants, understanding that the immigrant is often forced to leave his native country in search of a new better life, new opportunities and sometimes just to escape and survive.

Negative evaluations of an immigrant's personal qualities and behavior describe them from an opposite point of view, the number of newcomers is growing day by day, and immigrants sometimes cause a tight labor market, as local residents may lose their jobs due to the appearance of cheaper labor. As a further perspective can be the study of the neutral attitude towards immigrants, the reasons for the formation of a neutral image of an immigrant and the language means that form it.

\section{Conclusion}

This study has explored the expression of a positive and negative evaluation in the British social media discourse. Provided analysis showed that, the studied online materials on social media discourse both inform readers, and contribute to the formation of their evaluative attitude to the described events.

The author's evaluation, in particular, is expressed through evaluative communication strategies, such as the strategy of approval, the strategy of disapproval, the strategy of unambiguity positions and the strategy of conveying plurality of opinions. According to the thorough analysis, we have come to the conclusion that the key strategy of British social media discourse that presents the immigration issues is a strategy of disapproval. It is expressed through the tactics of a recognition of the existence of the problem, accusation, reproach, discredit, misunderstanding, doubt, indication of the future, disagreement, distancing implying negative evaluation. These evaluation strategies reflect the negative differences in the social sphere of the entire British society 
caused by the process of its exit from the European Union. Therefore, the used evaluation strategies contribute to the creation of a negative image of the object of evaluation and the corresponding attitude of the recipient.

In the further studies, it will be perspective to consider the readers' comments and determine which evaluation tool in the particular comment is primary and which tool prevails.

\section{References}

Actafurova, T.N. (1997). Cognitive and communicative aspect of strategies. In: Linguistic phenomena in the language system and in the text. Volgograd: Publishing House of Volgograd State University, 4-11.

Dragoi, A. (31.03.2019). An immigrant's tale: Leaving Britain to escape Brexit hostility. Independent. https://www.independent.co.uk/arts-entertainment/photography/immigrants-leaving-britain-escapebrexit-hostility-photos-a8841026.html

Glushko, I.V., Lavrukhina, I.M., Zueva, T.M., \& Ostapenko, I.A. (2019). Ethnic and migration components of social practices: opportunities to regain trust. Opción, 35(24), 106-121.

Gonzalez Duranrez, M. (26.11.2018). Cameron's arrogance hurt the country, but May's insults cut deep. The Guardian. https://www.theguardian.com/commentisfree/2018/nov/29/theresa-may-added-insult-toinjury-brexit

Gumperz, J.J. (1982). Discourse Strategies. Cambridge: Cambridge University Press.

Halliday, M.A.K., \& Matthiessen, Christian M.I.M. (2004). An Introduction to Functional Grammar. UK, London: Hodder Arnold.

Huston, S., \& Thompson, G. (Eds). (200o). Evaluation in Text. Authorial Stance and the Construction of discourse. UK, Oxford: Oxford University Press.

Issers, O.S. (2008). Communicative strategies and tactics of Russian speech. Moscow: Lki.

Kentish, B. (16.05.2019). Illegal immigration to UK will rise after Brexit, study suggests. Independent. https://www.independent.co.uk/news/uk/politics/brexit-illegal-immigration-free-movement-eu-leavea8915816.html

Martin, J.R. (2000). Beyond exchange: Appraisal systems in English. In: S. Hunston \& G. Thompson (Eds.), Evaluation in Text: Authorial Stance and the Construction of Discourse. UK, Oxford: Oxford University Press, $142-175$.

Martin, J.R., \& White, P.R.R. (2005). The Language of Evaluation: Appraisal in English. London: Palgrave Macmillan.

Parveen, N. (03.10.2019). Britain's 'nurse of the year' blames Brexit for mental breakdown. The Guardian. https://www.theguardian.com/politics/2019/oct/o3/britains-nurse-of-the-year-blames-brexit-for-mentalbreakdown

Proctor, K., \& Perraudin, F. (o8.12.2019). Critics attack Johnson's plan for 'Australian-style' migration system. The Guardian. https://www.theguardian.com/politics/2019/dec/o8/boris-johnson-lying-overimmigration-jonathan-ashworth

Rankin, J. (15.01.2020). Britain's EU citizens 'at risk of discrimination' after Brexit, say MEPs. The Guardian. https://www.theguardian.com/politics/2020/jan/15/eu-citizens-in-uk-risk-discrimination-in-jobs-andhousing

Tannen, Deborah. (1989). Talking Voices: Repetition, Dialogue, and Imagery in Conversational Discourse. Cambridge: Cambridge University Press. 
Van Dijk, T.A., \& Kintsch, W. (1988). Strategies of understanding cohesive text. In: V.V. Petrov \& V.I. Gerasimov (Eds.), New in foreign linguistics. Vol. XXIII. Cognitive aspects of language. Moscow: Progress, 153-211.

Walker, P. (11.02.2019). Immigration regime after Brexit 'risks new Windrush scandal'. The Guardian. https://www.theguardian.com/politics/2019/feb/11/immigration-regime-after-brexit-risks-new-windrushscandal

Wallis, D. (o9.11.2019). Forget the 'brightest and best' immigrants - we need to consider them all if we want any chance of thriving. Independent. https://www.independent.co.uk/voices/letters/general-electionbrightest-best-immigration-conservatives-berlin-wall-a9196666.html 